Новицька Н. В., кандидат сільськогосподарських наук, Барзо I. T., аспірант *

Національний університет біоресурсів і природокористування України

\title{
ОПТИМІЗАЦІЯ НІТРОГЕНАЗНОЇ АКТИВНОСТІ БУЛЬБОЧОК НУТУ НА ЧОРНОЗЕМАХ ТИПОВИХ ЛІСОСТЕПУ УКРАЇНИ
}

\section{Рецензент - кандидат сільськогосподарських наук В. М. Рожкко}

\begin{abstract}
Висвітлено результати досліджень впливу мінеральних добрив та інокуляиії насіння на ефективність нітрагінізації та врожайність нуту сорту Розанна. Встановлено, щуо внесення азотних добрив на чорноземах типових Правобережного Лісостепу України сприяє взаємодії мінерального азоту з природною популяцією бульбочкових бактерій.

Урожайність нуту сорту Розанна на варіантах без удобрення та при застосуванні інокуляції була вищзо, ніж на варіантах з внесенням добрив у нормі $N_{30} P_{60} K_{60}$ без інокуляиіӥ насіння.
\end{abstract}

Ключові слова: мінеральні добрива, інокуляція насіння, маса бульбочок, кількість бульбочок, нітрогеназна активність, урожайність.

Постановка проблеми. До нинішнього часу дискусійним залишається питання необхідності застосування азотних добрив у процесі вирощування бобових культур. Відомо, що азотні сполуки впливають на формування й функціонування бобово-ризобіального комплексу на всіх етапах формування та функціонування симбіозу, починаючи 3 утворення ризосфери та бульбочок і закінчуючи процесом активної азотфіксації [1].

Аналіз основних досліджень і публікацій, у яких започатковано розв'язання проблеми. Науковці Московської сільськогосподарської академії ім. Тимірязєва в польових та вегетаційних дослідах вивчали поведінку симбіонтів бобових культур за внесення різних доз азотних добрив. Ними встановлено, що підвищення в грунті вмісту розчинних азотовмісних з'єднань за оптимальних умов вирощування рослин у польових умовах не перешкоджає їх симбіозу із бульбочковими бактеріями. Зниження частки атмосферного азоту, який засвоюють рослини за підвищеної забезпеченості мінеральним азотом, має лише відносний характер [6]. Абсолютна кількість азоту, що засвоюється бактеріями з атмосфери, практично не знижується, у деяких випадках навіть підвищується порівняно 3 рослинами, які вирощують у присутності бульбочкових бактерій, але без внесення у грунт азотних добрив. Цієї ж думки дотримується Н. Н. Бабич [1], стверджуючи, що за умови створення сприят- ливого для бобових культур режиму азотного живлення можна досягти високих урожаїв. Тому не доцільно відмовлятись ні від одного, ні від іншого джерела надходження азоту.

Разом із цим, на думку В. I Січкара, О. В. Бушулян, С. В. Дідович та ін. $[2,3]$, внесення азотних добрив у нормах понад 60 кг/га в південних регіонах України пригнічуе розвиток бульбочкових бактерій, негативно впливаючи на ріст, розвиток i формування врожаю бобових культур. Численними дослідженнями 3 різними бобовими культурами чітко доведена інгібуюча дія мінерального азоту на рівень азотфіксації. Високі дози азотних мінеральних добрив зменшують кількість бульбочок на коренях, їх масу, а також нітрогеназну активність. Останні дослідження підтвердили цю тенденцію і для нуту [2].

Мета досліджень полягала у з'ясуванні впливу азотного мінерального живлення на ефективність нітрагінізації та врожайність нуту сорту Розанна.

Матеріали і методи досліджень. Польові дослідження проводили у 2010-2011 роках на полях кафедри рослинництва у ВП НУБіП України «Агрономічна дослідна станція». Грунт дослідного поля - чорнозем типовий малогумусний. Агрохімічні показники (0-30 см): гумус за Тюріним 4,38-4,53\%; pH (сольове) - 6,8-7,3; ємність поглинання 30,7-32,5 мг-екв. на 100 г грунту. У шарі 0-20 см загального азоту міститься 0,27-0,31\%, фосфору - 0,15-0,25 \%, калію - 2,3-2,5 \% [5].

Агротехніка у досліді - загальноприйнята для північного Лісостепу [4]. Нут висівали за температури грунту на глибині загортання насіння $6-8^{\circ} \mathrm{C}$ сівалкою «Клен» із нормою висіву 500 тис. насінин на 1 гектар. Мінеральні добрива вносили згідно зі схемою досліду: 1) контроль (без добрив); 2) NPK - 30:60:60;3) NPK - 60:60:60;4) NPK 90:60:60; 5) NPK - 120:60:60, вносили під основний обробіток грунту та під весняну культивацію.

Варіанти досліджень включали також обробку насіннєвого матеріалу бульбочковими бактеріями для нуту (ризобофіт - 1,5-1,7 л робочого розчину на $100-150$ кг насіння шляхом замочування насіння в день сівби).

* Науковий керівник-доктор сільськогосподарських наук, професор С. М. Каленська 


\section{Вилив мінерального азоту на ефективність симбіотичної азотфіксації та формування} врожаю нуту сорту Розанна (2010-2012 рр.)

\begin{tabular}{|c|c|c|c|c|c|c|c|c|}
\hline \multirow{2}{*}{$\begin{array}{c}\text { Варіант } \\
\text { досліду }\end{array}$} & \multicolumn{2}{|c|}{$\begin{array}{c}\text { Кількість бульбочок, } \\
\text { одиниць } / \text { рослину }\end{array}$} & \multicolumn{2}{c|}{$\begin{array}{c}\text { Біомаса бульбочок, } \\
\text { мг/ рослину }\end{array}$} & \multicolumn{2}{c|}{$\begin{array}{c}\text { Н.А.*, нМоль етилену } \\
\text { на рослину за годину }\end{array}$} & \multicolumn{2}{|c|}{ Урожай зерна, } \\
\cline { 2 - 9 } & $6 /$ га \\
\hline Контроль & 0 & $\mathrm{i}$ & $6 / \mathrm{i}$ & $\mathrm{i}$ & $6 / \mathrm{i}$ & $\mathrm{i}$ & б/i & $\mathrm{i}$ \\
\hline $\mathrm{N}_{30} \mathrm{P}_{60} \mathrm{~K}_{60}$ & 0 & 12,7 & 0 & 324 & 0 & 1725 & 2,68 & 2,91 \\
\hline $\mathrm{N}_{60} \mathrm{P}_{60} \mathrm{~K}_{60}$ & 0 & 17,0 & 0 & 561 & 0 & 3109 & 2,87 & 3,10 \\
\hline $\mathrm{N}_{90} \mathrm{P}_{60} \mathrm{~K}_{60}$ & 0 & 8,0 & 0 & 673 & 0 & 3971 & 3,16 & 3,41 \\
\hline $\mathrm{N}_{120} \mathrm{P}_{60} \mathrm{~K}_{60}$ & 0 & 1,4 & 0 & 2 & 0 & 0 & 2,88 & 3,07 \\
\hline
\end{tabular}

Примітка: * Н.А. - нітрогеназана активність

Результати досліджень. Проведені дослідження свідчать, що внесення азотних добрив на чорноземах типових Правобережного Лісостепу України сприяє взаємодії мінерального азоту 3 природною популяцією бульбочкових бактерій. У середньому за роки досліджень на всіх варіантах без інокуляції насіння та з низькими і середніми дозами азотних добрив врожайність нуту сорту Розанна була нижчою, порівняно з варіантами удобрення, на яких інокуляцію насіння застосовували. Без штучного зараження насіння бактеріями на бульбочки на коренях нуту не утворювалися, відповідно, й нітрогеназна активність не відбулася, - тому врожай на цих варіантах формувався виключно за рахунок мінерального живлення рослини. У варіантах із застосуванням інокуляції відмічено помітний приріст урожаю. Так, найвищу врожайність нуту $(3,41$ т/га) відмічено на варіанті досліду за внесення добрив у дозі $\mathrm{N}_{60} \mathrm{P}_{60} \mathrm{~K}_{60}$ та інокуляції насіння. На даному варіанті основні показники симбіотичної діяльності сягнули найвищої в досліді відмітки: кількість бульбочок - 17,2 шт./рослину, біомаса бульбочок - 673 мг/рослину та нітрогеназна активність становила 3971 нМоль етилену/год. (див. табл.).

Подальше збільшення добрив до $\mathrm{N}_{120} \mathrm{P}_{60} \mathrm{~K}_{60}$ призвело до зниження урожайності нуту, поскільки азотні добрива у нормі від 90 кг/га д.р. і вище пригнічують азотфіксацію, де бульбочки хоча й утворювалися у незначній кількості, проте нітрогеназ-

\section{БІБЛІОГРАФІЯ}

1. Бабич Н. Н. Бактеризация - прием повышения производства белка // Зерновые культуры. 1997. - № 3. - C. 19-20.

2. Бушулян O. B., Січкар В. I. Нут: генетика, селекція, насінництво, технологія вирощування: Монографія. - Одеса, 2009. - 248 с.

3. Дідович С. В., Портянко С. І., Дідович О. М. Вплив мінерального азоту на ефективність симбіозу нуту (Cicer arietinum L.) з Mesorhizobium ciceri // Тези наук. конф. молодих учених (Ужгород, 1-3 грудня 2005 р.). - Ужгород, 2005. - С. 48-49.

4. Довідник з вирощування зернових та зернобо- на активність майже не відбувалася. Тому на варіантах із максимальними дозами азотних добрив, як за використання інокуляції насіння, так і без неї, урожайність даного сорту знаходилася майже на одному рівні. Так як азотфіксації з повітря не відбувалося через відсутність нітрогеназної активності, то на цих варіантах рослини мали виключно мінеральну форму живлення.

Підсумовуючи результати досліджень, слід зауважити, що збільшення норм внесення азотних добрив позитивно впливає на формування врожаю нуту до певної межі. Зокрема, збільшення норм азотних добрив до $\mathrm{N}_{60}$ на фоні $\mathrm{P}_{60} \mathrm{~K}_{60}$ сприяє підвищенню врожаю, проте подальше збільшення до $\mathrm{N}_{120}$ призводить до зниження цього показника. Застосування інокуляції насіння у поєднанні з внесенням певних доз мінеральних добрив $\left(\mathrm{N}_{30}-\mathrm{N}_{60}\right.$ на фоні $\left.\mathrm{P}_{60} \mathrm{~K}_{60}\right)$ сприяло одержанню значних приростів урожайності зерна досліджуваної культури.

Висновки. Проведені дослідження свідчать, що урожайність нуту сорту Розанна на варіантах без удобрення та при застосуванні інокуляції була дещо вищою, ніж на варіантах із внесенням добрив у нормі $\mathrm{N}_{30} \mathrm{P}_{60} \mathrm{~K}_{60}$ без інокуляції насіння. Тому очевидним як $з$ економічної, так і з екологічної точок зору доцільніше при вирощуванні нуту використовувати природний азот за передпосівної інокуляції насіння на противагу використанню мінерального азоту.

бових культур / [В. В. Лихочвор, М. І. Бомба, С. В. Дубковецький та ін.]. - Львів : Українські технології, 1999. - $408 \mathrm{c}$.

5. Дубровіна Н. Я. Грунти агрономічної дослідної станції «Митниця» Васильківського району Киівської області // Наукові праці Укр. с.-г. академіі. - Вип. 123 / Біологія і агротехніка польових культур в Поліссі і Лісостепу УРСР / Н. Я. Дубровіна, О. М. Аксіом. - К., 1974. - С. 3-17.

6. Шпаар Д., Эллмер Ф., Постников А [и др.]. Зернобобовые культуры / Под общей редакцией Д. Шпаара. - Мн. : ФУАинформ, 2000. - 264 с. 